\title{
EFEKTIFITAS OVITRAP LAMPU PUTIH DENGAN RENDAMAN FERMENTASI TERHADAP NYAMUK TERPERANGKAP DI PUSKESMAS BERINGIN TIGA 2021
}

\author{
Rustam Aji ${ }^{1}$ \\ ${ }^{1}$ Prodi Keperawatan Curup Poltekkes Kemenkes Bengkulu \\ adjieroestamadjie@gmail.com.
}

\begin{abstract}
ABSTRAK
Perilaku hidup nyamuk yang suka terbang ke udara dengan berat tubuh yang ringan membuat nyamuk mudah terbawa angin, pada malam hari nyamuk terbang menuju arah penerangan. Keberadaan nyamuk bisa merugikan kesehatan manusia, karena nyamuk bisa menularkan penyakit dalam kehidupan manusia. Peneliti tertarik untuk mengendalikan populasi nyamuk perlu dilakukan suatu usaha untuk mengurangi populasi nyamuk. Tujuan penelitian untuk mengetahui efektifitas modifikasi ovitrap pencahayaan lampu warna putih, dengan modifikasi rendaman fermentasi gula merah dan ragi, pada kelompok intervensi dan kelompok kontrol. Survei lokasi nyamuk sebanyak 36 tempat kamar mandi. Penelitian observasional, desain cross sectional study. Data hasil survei dianalisis menggunakan uji chi-square. Hasil penelitian hampir sebagian besar dari 28 nyamuk (77.8\%) dari 36 nyamuk terperangkap dalam alat ovitrap lampu putih dalam $50 \mathrm{ml}$ air rendaman fermentasi dalam waktu 24 jam. Berdasarkan analisis Chi-square diperoleh nilai $\mathrm{P}=0.004<\alpha \quad 0.05$. Maka Ho ditolak dan Ha diterima secara statistik ada hubungan yang signifikan antara Efektifitas Modifikasi Alat Ovitrap terhadap nyamuk terperangkap dalam alat ovitrap lampu putih, dengan rendaman fermentasi Dimana nilai OR $=4.37$ berarti pengaruh Efektifitas Modifikasi Ovitrap lampu putih dengan rendaman fermentasi gula merah dan ragi efektif, 4.10 kali ditemukan adanya nyamuk terperangkap.
\end{abstract}

\section{Keywords: Ovitrap, lampu putih dan nyamuk.}

\begin{abstract}
The life behavior of mosquitoes that like to fly into the air with a light body weight makes it easy for mosquitoes to be carried by the wind, at night the mosquitoes fly towards the lighting. The presence of mosquitoes can harm human health, because mosquitoes can transmit diseases in human life. Researchers interested in controlling the mosquito population need to make an effort to reduce the mosquito population. The purpose of the study was to determine the effectiveness of the modified white light ovitrap fermentation bath on trapped mosquitoes, in the intervention group and the control group. Survey of mosquito locations as many as 36 bathrooms. Observational research, cross sectional study design. The survey data were analyzed using the chi-square test. The results of the study were that most of the 28 mosquitoes $(77.8 \%)$ of the 36 mosquitoes were trapped in a white light ovitrap device in $50 \mathrm{ml}$ of fermented soaking water within 24 hours of being placed in the bathroom. Based on Chi-square analysis, the value of $\mathrm{P}=0.004<0.05$ was obtained. So Ho is rejected and Ha is accepted statistically there is a significant relationship between the effectiveness of the modified white light ovitrap fermentation bath on trapped mosquitoes.
\end{abstract}

Keywords: Ovitrap, white light and mosquito

Volume XI No. 2 Desember $2021 \mathrm{Hal}$ - 123 


\section{PENDAHULUAN}

Membebaskan diri dari gigitan nyamuk merupakan suatu tindakan yang harus dilakukan dalam rangka menciptakan suasana aman dari segala resiko/efek gigitan nyamuk. Efek dari gigitan nyamuk sangat merugikan bagi manusia, yang paling ringan diantaranya dapat menyebabkan gatal- gatal dan segala dampak yang ditimbulkannya juga sangat mengganggu aktifitas kita. Akibat yang lebih berbahaya lagi dari gigitan nyamuk adalah terjangkitnya wabah penyakit Demam Berdarah Dengue (DBD) yang penularannya melalui gigitan nyamuk Aides aigepty (WHO,2001).

Pada tahun 2015 Incidence Rate (IR) DBD di Indonesia adalah sebesar 50,75 per 100.000 penduduk dengan Case Fatality Rate (CFR) sebesar $0,83 \%$ di tahun 2015 yang kemudian meningkat di tahun 2016 menjadi sebesar 78,85 per 100.000 penduduk dengan CFR sebesar 0,78\%. Di tahun 2017 IR DBD di Indonesia sebesar 22,55 per 100.000 penduduk dengan CFR sebesar $0,75 \%$. (Inila,2020, Kementerian RI, 2013).

Nyamuk Aedes aegypti merupakan nyamuk vektor yang membawa virus dengue penyebab penyakit Demam Berdarah Dengue (DBD) yang masih menjadi masalah kesehatan di Indonesia baik bagi tenaga kesehatan maupun masyarakat (Aji, 2017).

Demam berdarah dengue merupakan salah satu peyakit yang sampai saat ini masih menjadi masalah kesehatan di Indonesia baik bagi tenaga kesehatan maupun masyarakat,sehingga dapat mengkhawatirkan terjangkit penyakit demam berdarah dimasyarakat (Aji, 2017).

Perkembangan nyamuk menjadi banyak ketika musim penghujan dan nyamuk berterbangan masuk kerumah bahkan menggigit siapapun yang dijumpai (Aji, 2019).

Populasi nyamuk dilingkungan masyarakat cukup banyak, hal ini dipengaruhi oleh bentuk anatomi nyamuk yang relatif kecil dan mampu beradaptasi dengan berbagai kondisi lingkungan. Aji (2019)Nyamuk Aedes aegypti merupakan nyamuk vektor yang membawa virus dengue, virus ini dapat menyebabkan penyakit Demam Berdarah Dengue (DBD) (Aji, 2019).

Persebaran spesies nyamuk Aedes aegypti saat ini selain ditemukan di daerah perkotaan (urban) juga ditemukan didaerah pedesaan (Kementerian Kesehatan RI, 2017).

Perilaku hidup nyamuk yang suka terbang ke udara dengan berat tubuh yang ringan membuat nyamuk mudah terbawa angin, pada malam hari nyamuk terbang menuju arah penerangan (Aji,2016).

Keberadaan nyamuk bisa merugikan kesehatan manusia, karena nyamuk bisa menularkan penyakit dalam kehidupan manusia. Populasi nyamuk semakin tak terkendali. Peneliti tertarik untuk mengendalikan populasi nyamuk perlu dilakukan suatu usaha untuk mengurangi populasi nyamuk (Aji, 2017).

Fenomena ketika peneliti mengamati perilaku serangga dan nyamuk dimalam hari, ada yang berterbangan mendekati lampu teras rumah yang sedang menyala.Peneliti tertarik dan mendapatkan ide, untuk melakukan penelitian tentang modifikasi alat ovitrap yang pernah peneliti buat dari botol plastik yang diberi fermentasi gula merah, ragi dan air, dimana aroma fermentasi dapat mengundang penciuman serangga dan nyamuk untuk datang. Penelitipun mendapatkan ide, bagaimana bila ovitrap dari botol plastik jika di beri pencahayaan lampu warna putih, apakah bisa mengundang nyamuk untuk mendekati sinar cahaya warna putih ? ini harus dilakukan percobaan.

Menurut peneliti ini sebagai bentuk keterbaruan dalam penelitian ini adalah model alat perangkap mengundang nyamuk dengan pencahayaan lampu warna putih,pada model alat ovitrap lampu putih dengan modifikasi fermentasi gula merah,ragi dan air. 
Maka berdasarkan fenomena tersebut diatas , peneliti mengangkat tema judul penelitian yaitu : "efektifitas ovitrap lampu putih dengan rendaman fermentasi terhadap nyamuk terperangkap di Puskesmas Beringin Tiga 2021"

\section{METODE PENELITIAN Desain Penelitian}

Jenis dan rancangan dalam penelitian ini peneliti menggunakan desain quasi eksperimen, dengan post test only control group design yaitu ada kelompok eksperimen dan ada kelompok kontrol. Pada kelompok eksperimen diberikan perlakuan X1 dan pada kelompok kontrol tidak diberikan perlakuan (Nursalam, 2008). Dan pada akhir penelitian kedua kelompok dikenai post test. Pemilihan subjek ke dalam kedua kelompok yang dikenai eksperimen menggunakan proses randomisasi. dengan asumsi randomisasi, kedua kelompok yang dikenai eksperimen adalah ekuivalen (hampir sama).

\section{Kerangka Konsep}

Tabel 1.

Desain posttest only control group design

\begin{tabular}{|c|l|c|}
\hline Kelompok & \multicolumn{1}{|c|}{ Perlakuan (X) } & Post Test \\
\hline K1 & $\begin{array}{l}\text { Ovitrap dengan } \\
\text { Lampu biru dan } \\
\text { kuning }\end{array}$ & O1 \\
\hline $\begin{array}{l}\text { Ovitrap tanpa } \\
\text { lampu Tdk } \\
\text { diberikan perlakuan }\end{array}$ & \\
\hline
\end{tabular}

Keterangan :

K1 : Kelompok Eksperimen (kelompok yang diberi perlakuan Ovitrap dengan Lampu biru dan kuning )

K2 : Kelompok Kontrol (kelompok Ovitrap tanpa lampu Tdk diberikan perlakuan )

O1 : Post-test (kelompok eksperimen)

O2 : Post-test (kelompok kontrol)

$\mathrm{X}$ : Perlakuan (Ovitrap dengan Lampu biru dan kuning).

Peneliti akan membagi responden menjadi dua kelompok. Kelompok I adalah kelompok eksperimen yang mendapat perlakuan Ovitrap dengan Lampu biru dan kuning dan kelompok II adalah kelompok kontrol yang tidak mendapat perlakuan lampu. Kemudian peneliti menilai efektifitas model alat perangkap mengundang nyamuk dengan pencahayaan lampu warna biru dan kuning,pada modifikasi botol plastik ovitrap, dengan menggunakan visual analogue scale kelompok I (O1) dan kelompok II (O2).

\section{Hipotesis Penelitian}

Hipotesis dalam penelitian ini diantaranya adalah:

1. Ha : Lebih efektifitas model alat perangkap mengundang nyamuk dengan pencahayaan lampu warna biru dan kuning,pada modifikasi botol plastik ovitrap

2. Ha : Tidak efektifitas model alat perangkap mengundang nyamuk dengan pencahayaan lampu warna biru dan kuning,pada modifikasi botol plastik ovitrap

\section{Definisi Operasional}

Variabel dalam penelitian ini adalah efektifitas model alat perangkap mengundang nyamuk dengan pencahayaan lampu warna biru dan kuning,pada modifikasi botol plastik ovitrap, seperti terlihat pada tabel 3 .

\section{Analisa Univariat}

Analisa ini bertujuan untuk mengetahui gambaran distribusi frekuensi masingmasing variabel penelitian dengan menggunakan ukuran proporsi.

Rumus yang digunakan :

$$
\mathrm{P}=\frac{\mathrm{F}}{\mathrm{N}} \times 100 \%
$$

Keterangan :

$\mathrm{P}=$ Proporsi / jumlah persentase

$\mathrm{F}=$ Jumlah frekwensi jawaban untuk setiap alternatif jawaban

$\mathrm{N}=$ Jumlah responden 
Dari rumus diatas nilai proporsi yang didapat dalam bentuk persentase, yang didapat di interprestasikan dan menggunakan skala Arikunto (2002) :

$0 \%=$ Tidak satupun dari Responden $1 \%-25 \%=$ Sebagian kecil dari Responden
$26 \%-49 \%=$ Hampir sebagian dari responden $50 \%=$ Setengah dari responden $51 \%-75 \%=$ Sebagian besar dari responden $76 \%-99 \%=$ Hampir seluruh responden $100 \%=$ Seluruh responden

Tabel 2.

Definisi Operasional

\begin{tabular}{|c|c|c|c|c|}
\hline Variabel & Definisi Operasional & Cara ukur & Hasil Ukur & Skala \\
\hline \multicolumn{5}{|l|}{ Bebas } \\
\hline Ovitrap & $\begin{array}{l}\text { Alat } \\
\text { nyamuk }\end{array}$ & $\begin{array}{l}\text { Observasi jumlah } \\
\text { nyamuk } \\
\text { terperangkap }\end{array}$ & $\begin{array}{l}0=\text { tidak ada } \\
\text { nyamuk } \\
1=\text { ada nyamuk }\end{array}$ & Ratio \\
\hline \multicolumn{5}{|l|}{ Terikat } \\
\hline $\begin{array}{l}\text { Pencahayaan } \\
\text { lampu }\end{array}$ & $\begin{array}{l}\text { Pencahayaan lampu } \\
\text { putih }\end{array}$ & $\begin{array}{l}\text { Kelompok } \\
\text { intervensi dan } \\
\text { kelompok kontrol } \\
\text { diberi lampu dan } \\
\text { tidak diberi lampu }\end{array}$ & $\begin{array}{l}0=\text { tidak ada } \\
\text { nyamuk } \\
1=\text { ada nyamuk }\end{array}$ & Ratio \\
\hline
\end{tabular}

\section{Populasi dan Sampel}

Populasi penelitian ini adalah seluruh nyamuk dengan sampel diambil dari populasi dengan teknik consecutive sampling, sebanyak 72 nyamuk yang memenuhi. Kriteria inklusi. Pada kelompok intervensi jumlah sampel 36 nyamuk dan 36 nyamuk pada kelompok kontrol,satu banding satu. Kriteria ekslusi: Serangga lain.

\section{Tempat dan Waktu Penelitian}

Lokasi Penelitian di Wilayah Kerja Puskesmas Beringin Tiga. Waktu dari bulan Agustus sampai dengan Desember 2021.

\section{HASIL PENELITIAN}

\section{Analisis Univariat}

Mengetahui rata-rata efektifitas model alat modifikasi ovitrap dengan pencahayaan lampu warna putih, dengan modifikasi botol plastik ovitrap rendaman fermentasi gula merah dan ragi pada kelompok intervensi dan kelompok kontrol.

Tabel 3 menunjukkan hasil penelitian dimana hampir sebagian besar dari 28 nyamuk $(77.8 \%)$ dari 36 nyamuk terperangkap dalam alat ovitrap lampu putih dalam $50 \mathrm{ml}$ air rendaman fermentasi dalam waktu 24 jam.

Tabel 3. Analisis Univariat

\begin{tabular}{|c|c|c|c|c|c|c|c|c|c|c|c|}
\hline \multirow[t]{3}{*}{$\mathrm{NO}$} & \multirow{3}{*}{$\begin{array}{l}\text { Variabel } \\
\text { indepen } \\
\text { den } \\
\text { Nyamuk }\end{array}$} & \multicolumn{4}{|c|}{ Efektifitas } & \multirow{2}{*}{\multicolumn{2}{|c|}{ Jumlah }} & \multirow{3}{*}{$\mathrm{P}$} & \multirow{3}{*}{ OR } & \multicolumn{2}{|c|}{$\mathrm{CI}(95 \%)$} \\
\hline & & \multicolumn{2}{|c|}{$\begin{array}{c}\text { Ovitrap } \\
\text { biasa }\end{array}$} & \multicolumn{2}{|c|}{$\begin{array}{c}\text { Ovitrap } \\
\text { Fermentasi }\end{array}$} & & & & & Lower & $\begin{array}{l}\text { Uppe } \\
\text { r }\end{array}$ \\
\hline & & $\mathrm{F}$ & $\%$ & $\mathrm{~F}$ & $\%$ & $\mathrm{~F}$ & $\%$ & & & & \\
\hline 1 & $\begin{array}{l}\text { Tanpa } \\
\text { Lampu }\end{array}$ & 20 & 55.6 & 8 & 22.2 & 28 & 38.9 & \multirow[t]{3}{*}{0,004} & \multirow[t]{3}{*}{4.37} & \multirow[t]{3}{*}{1.57} & \multirow[t]{3}{*}{12.19} \\
\hline 2 & $\begin{array}{l}\text { Lampu } \\
\text { Putih }\end{array}$ & 16 & 44.4 & 28 & 77.8 & 44 & 61.1 & & & & \\
\hline \multicolumn{2}{|c|}{ Total } & 36 & 100 & 36 & 100 & 72 & 100 & & & & \\
\hline
\end{tabular}




\section{Analisis Bivariat}

Berdasarkan analisis Chi-square diperoleh nilai $\mathrm{P}=0.004<\alpha \quad 0.05$. Maka Ho ditolak dan Ha diterima secara statistik ada hubungan yang signifikan antara Efektifitas Modifikasi Alat Ovitrap terhadap nyamuk terperangkap dalam alat ovitrap lampu putih, dengan rendaman fermentasi Dimana nilai OR $=4.37$ berarti pengaruh Efektifitas Modifikasi Ovitrap lampu putih dengan rendaman fermentasi gula merah dan ragi efektif, 4.10 kali ditemukan adanya nyamuk terperangkap.

\section{PEMBAHASAN}

Karena perilaku hidup nyamuk yang suka terbang ke udara dengan berat tubuh yang ringan membuat nyamuk mudah terbawa angin, pada malam hari nyamuk terbang menuju arah penerangan, yang sudah dibuat oleh peneliti pada alat ovitrap botol plastik bekas minuman mineral, yang peneliti bungkus, direkatkan dengan staples dan di beri lem plastik serta dibungkus plastik warna biru, dan didalam botol ovitrap diberi pencahayaan lampu warna biru,sehingga mata nyamuk tertarik terbang kearah lampu berwarna biru, disamping ovitrap menebarkan aroma yang menguap karena terkena panas lampu dari dalam botol plastik serta memancing penciuman nyamuk pada aroma karbordioksida (CO2) yang ditimbulkan dari aroma fermentasi racikan gula merah, ragi dan air, (Aji,2020) Sehingga nyamuk terbang masuk menuju arah sinar dan aroma dari dalam lobang ovitrap yang sudah siap menjerat nyamuk.

Rustam Erlina, dkk,(2016) hasilnya bahwa menunjukkan perbedaanjumlah telur Aedes spp yang terdapat pada masingmasing media ovitrap.Disimpulkan bahwa air jerami lebih efektif sebagai media ovitrap dari pada airmineral, air kolam, dan air sumur.

Sependapat penelitian, Wahidah Asriati, dkk (2016) hasil penelitiannya; Jumlah telur nyamuk yang paling banyak terperangkap pada ovitrap yaitu terdapatpadaair biasa (kontrol) sebesar 238 telur.

Sependapat penelitian Zubaidah Tien dkk (2016), hasil penelitiannya, menunjukkan perbedaan konsentrasi atraktan dan warna ovitrap, memberikan pengaruh yang nyata dalam menjebak nyamuk Aedes sp untuk bertelur didalamovitrap.

\section{KESIMPULAN}

Pada model alat ovitrap yang di modifikasi fermentasi gula merah dan ragi serta air didalam botol ovitrapm terkena panas oleh cahaya lampu, serta menimbulkan dan menebarkan aroma yang menguap dari dalam botol plastik serta memancing penciuman nyamuk pada aroma karbordioksida (CO2) yang ditimbulkan dari aroma fermentasi racikan gula merah, ragi dan air,sehingga nyamuk tertarik terbang masuk menuju arah sinar cahaya putih, dan aroma dari dalam lobang ovitrap yang sudah siap menjerat nyamuk.

\section{SARAN}

Dinas Kesehatan diharapkan dapat mensosialisasikan kemasyarakat mengenai penggunaan ovitrap sebagai salah satu alternatif dalam pengendalian vektor nyamukAedes aegypti, dengan hanya menggunakan botol plastik minuman bekas air mineral.

Perlu dilakukan penelitian lanjut dengan model alat ovitrap modifikasi fermentasi berdasarkan musim penghujan atau musum panas serta musim pancaroba.

\section{DAFTAR PUSTAKA}

Arikunto Suharsimi (2002) Manajemen Penelitian. Jakarta. Rhineka Cipta.

Aji Rustam (2015) Identifikasi Survei Jentik Aedes Aegypti, Culex dan Aedes Albopictus padaLingkungan Non TPA di dalam dan Luar Rumah.(Peneliti:Rustam Aji)Penerbit:2-Trik:Tunas-Tunas 
Riset

Kesehatan.Alamat

Website:www.2Trik.webs.com

.ISSN:2086-3098. Vol.V.Nomor:4,

November 2015.hlm:223-229. Jurnal

Nasional

Aji Rustam. Muhammad Totong Kamaludin, Salni dan Sriati (2016) Environmental factors and indices related to gengue vector lanva in Rejang Labong District Tahun 2016. Penerbit: Irjpeh.(International Research Journal of Public and Environmental Health). (Tim: 1.Rustam Aji,2.Muhammad Totong Kamaluddin,3. Salni dan 4.Sriati. alamat

(URL/Linl:http://dx.doi.org/10.1573

9/irjpeh.16.021.).ISSN:2360-

8803.irjpeh.Vol.3(7),pp.162-

166,july-2016).Journal International.

Aji Rustam dan Chandra Buana (2017) Model Community Action by Level Density Larva of Aedes Aegypti Landfill Village in Batu Galing Sub District Curup Tengah.Penerbit Ejbps (European Journal of Biomedical and Pharmaceutical Sciences). Web adress: www.ejbps.com URL: URL Link https://www.ejbps.com/ejbps/ab stract_id/2216. dan Indexing Details is

available on https://www.ejbps.com/ ejbps/indexing.ISSN:2349-

8870.Vol.4.Issue.3.47-52-

year:2017)SJIF Impact Factor 4.382. Journal International.

Aji Rustam (2017) Pengaruh Serai Wangi terhadap Keberadaan Larva Aedes Aegypti pada Tempat penampungan Air. Penerbit:JVK (Jurnal Vokasi Kesehatan) alamat web-LinkURL:http://ejournal.poltekkespontianak.ac.id/index.php/JVK.ISSN :2442-5478. Vol.3.(1)(2017)hlm390-393. Jurnal Nasional.
Aji Rustam (2017) Effect of Boiled Carica Papaya Leaf on Death of Aedes Aegypti Larvae. (Peneliti: Rustam Aji). Penerbit:Journal of Epidemiology and Public Health.eISSN:2549-0273 (online). alamat wen-URL-Link:

https://doi.org/10.26911/jepublicheal th.2017.02.03.05.Vol.2(3)hlm:236-

\section{Journal International.}

Aji Rustam (2019) Pengaruh Air Rendaman Getah Pepaya Terhadap Kematian Jentik Aedes Aegypti.Penerbit: Penerbit Jurnal Kesehatan :Jurnal Ilmiah Multi Sciences.Siti Khadijah Palembang.Vol.IX.No.2- Desember 2019.hlm:108-115. ISSN: 9772087484DD4. e-Issn: 977-686367005 .almt web. URL LINK:https://doi.org/10.52395/jkjim s.v10i02.298.

Aji Rustam (2019) The Role of DBD Coordinator Nurses and Jumantic Kader on the Management of Muaro Jambi District Type Desnsity in Puskesmas Perumnas of Rejang Lebong District and Health Center of Muaro Jambi District in 2019.Publisher:Poltekkes Kemenkes Bandung:Proceeding of the 2nd International Conference on Interprofesional Health Colloboration and Community Empowerment. Bandung.5-6 Desember 2019. Alamat Web.URL-Link:

http://conference.juriskes.com/index. php/IC/article/view/94/59-ICIHCCE Poltekkes Kemenkes Bandung. Vol.2.issue.1.pages.42.2019/12/15. Proceeding Jurnal International

Aji Rustam (2019) Pengaruh Air Rendaman Kulit Batang Pepaya Terhadap Kematian Jentik Aedes Aegypti pada Tempat Penampungan Air di Kecamatan Curup Tengah.Penerbit:Jurnal Mandiri-Poltekkes Kemenkes 
Padang.P-ISSN:19708-8517,e-

ISSN:2615-8760.alamat web-URLLink:

http://jurnal.poltekkespadang.ac.id/o js//index.php/jsm.Vol.14 No:1-Juni2019. Jurnal Nasional.

Aji Rustam (2020)_Pengaruh Alat Ovitrap Air Rendaman Jerami Padi Dan Olesan Minyak Pada Botol Plastik Terhadap Nyamuk Terperangkap Di Desa Rimbo Recap Kecamatan Curup Selatan.Penerbit Jurnal Kesehatan :Jurnal Ilmiah Multi Sciences.Siti Khadijah Palembang.Vol 10.issue:02. Desember-2020. Pages:144-150. published Dec 1, 2020 .ISSN: 9772087484DD4. e-Issn: 977-686367005 .almt web. URL LINK:https://doi.org/10.52395/jkjim s.v10i02.298.

Dep.Kes.RI.(2000) Pencegahan dan Penanggulangan Penyakit DBD. Petunjuk Lengkap Terjemahan oleh Suroso, T. Dkk dari Prevention Control of Dengue Haemorrhagic. WHO dan Departemen Kesehatan.

Kementerian Kesehatan RI (2017) Pedoman Pencegahan dan Pengendalian Demam Berdarah Dengue diIndonesia.Direktorat Jenderal Pencegahan dan Pengendalian Penyakit.

Kementerian RI (2013) Pengembangan Dispenser Anti Nyamuk Dalam Menurunkan Kepadatan Nyamuk Demam Berdarah. Dir. Jen. Pengendalian Penyakit dan Penyehatan Lingkungan (Dir.Jend. $\mathrm{P}$ \& PL) Jakarta.

Nursalam (2008) Konsep dan Penerapan Metodologi Penelitian Keperawatan (Pedoman Skripsi, tesis dan instrumen Penelitian Keperawatan) Jakarta. Salemba Medika.
Rustam Erlina, Hasmiwati dan Rati Gusti,(2016) Perbandingan Efektifitas Berbagai Media Ovitrap Terhadap Jumlah Telur Aedes spp yang terperangkap di Kelurahan Jati Kota Padang. Jurnal Kesehatan Andalas.;5(2).Web:

http/jurnal.fk.unand.ac.id.

Wahidah Asriati, Martini, dan Hastiningsih Retno, (2016). Efektifitas Jenis Atraktan Yang digunakan Dalam Ovitrap Sebagai Alternatif Pengendalian Vektor DBD di Kelurahan Bulusan. Jurnal Kesehatan Masyarakat (e-Journal).Vol 4.Nomor 1. Januari 2016 (ISSN:2356-3346). web:http://ejournal-

s.1.undip.ac.id/index.php/jkm.

WHO (2001) Modul pedoman Penatalaksanaan Kasus DBD. Jakarta. EGC.Zubaidah Tien, Erminawati dan Ratodi Muhamad, (2016) Modifikasi Ovitrap DalamMeningkatkan Daya Jebak Telur Nyamuk Aedes sp di Kota Banjarbaru.Poltekkes Kemenkes Banjarmasin. 
